\title{
PSEUDO EMPOWERMENT: TRACKING THE LEVEL OF COMMUNITY EMPOWERMENT IN THE ECOTOURISM AREAS DEVELOPMENT IN BANGKA ISLAND, INDONESIA
}

\author{
Ibrahim IBRAHIM* \\ Universitas Bangka Belitung, Political Science Department Balunijuk, Bangka, Indonesia, e-mail: iim _babel@yahoo.com \\ Nizwan ZUKHRI \\ Universitas Bangka Belitung, Management Department Balunijuk, Bangka, Indonesia, e-mail: nizwan_ubb@yahoo.com \\ Rendy RENDY \\ Universitas Bangka Belitung, Political Science Department Balunijuk, Bangka, Indonesia, e-mail: rendy@mail.ugm.ac.id
}

\begin{abstract}
Citation: Ibrahim, I., Zukhri, N., \& Rendy, R. (2021). PSEUDO EMPOWERMENT: TRACKING THE LEVEL OF COMMUNITY EMPOWERMENT IN THE ECOTOURISM AREAS DEVELOPMENT IN BANGKA ISLAND, INDONESIA. GeoJournal of Tourism and Geosites, 39(4spl), 1397-1405. https://doi.org/10.30892/gtg.394spl10-783
\end{abstract}

\begin{abstract}
The development of an ecotourism area needs local residents' involvement for the proper management integrating with the conditions of local wisdom, and also empowers the community. Bangka Island, located in South Sumatra, Indonesia, is used as an alternative post-mining area for the tourism sector and acts as an interesting locus to assess the level of community empowerment. This study aims to trace the working process of the empowerment dimension in the development of ecotourism in Bangka Island. The quantitative descriptive method was used to collect data from 260 respondents spread across various districts/cities in Bangka Island. The result showed that the level of empowerment in Bangka Island is still very limited, tends to be elitist, and lacks economic benefits. However, interestingly, the community supports future development despite not being certain of their involvement in the process. This study also reveals that empowerment is still pseudo in this community, which means that it has not touched all aspects of the essence of empowerment due to a sense of pride in their region's popularity.
\end{abstract}

Key words: empowerment, ecotourism, local community, development, Bangka

\section{INTRODUCTION}

The development of the tourism sector in a community, which simultaneously supports an alternative economy, is closely related to two main aspects. The first is the community's extent involved with the government and other business actors during the development process. The second is the extent to which the community is involved in the empowerment process. Besides, these aspects are relevant because of the economic impact. The problems associated with developing this sector in certain areas are divided into two, namely, management by private business actors and directly controlled by the government. Although it was discovered that the local residents or neighboring communities mostly initiate the development of an ecotourism area, the existence of government plays a significant role (Mafruhah et al., 2018).

The development of an ecotourism area has indeed experienced several fundamental challenges. It includes the issue of business opportunities that supports the economy of the neighboring areas, the tug of war over ownership and management, implications associated with the culture of the surrounding local communities, as well as the readiness to embrace social transformation. Generally, the aforementioned problems are closely related to polemic management control. This implies that the private sector's ecotourism areas do not usually involve the local communities, whereas the reverse is the case with the government. However, the development of a tourism sector is closely influenced by the surrounding communities.

In addition, concern, and interest in the development of this sector, also determines the level of community empowerment. Based on the beneficial aspect, community empowerment dimensions to any degree are extremely relevant because it is in direct contact with efforts to boost welfare. Bangka is an archipelago that comprises stunning stretches of beaches and islands. According to Sulista et al. (2019), this is also known as a mining area, which has the potential for optimally developing ex-mining areas. In recent years, local governments in these islands have realized the impact of mining on the economy. Furthermore, the tourism sector's development is also perceived as an alternative for future economic growth (Ibrahim et al., 2019). This creates a multiplier effect condition alongside several other impacts it has on the neighboring communities and routes commonly used by tourists (Nugroho et al., 2018). Generally, this research focuses on the management of ecotourism or environmental tourism in Bangka Island. Nature is a tourist locus developed with environmental management principles. The development of an ecotourism area is closely related to the fundamental objectives and strategies used to boost the regional economy. These include community involvement and economic strengthening as the general goal of developing a tourism area. Community involvement in tourism development is important because it is related to empowerment. According to Butarbutar and Soemarno (2012) and Ngurah and Utama (2018), broad

\footnotetext{
* Corresponding author
} 
access to neighboring communities facilitates the mobilization of social capital and local resources while enhancing the empowerment quality. The general livelihoods of the Bangka Island people is predominately agriculture and tin mining (Bidayani and Kurniawan, 2020; Sulista, 2019; Ibrahim et al., 2018a; Rosyida et al., 2019; Punaweni et al., 2019a), with little variation in the world of tourism. This is because community empowerment has not run optimally in the midst of ecotourism, at least in terms of economic income. Therefore, it is important to explore this problem to identify the basic problems from the aspect of community empowerment. This is because a weak community empowerment only benefits the owners of capital.

According to Zimmerman (2000) empowerment is an effort to develop community, improve the quality of life, and provide opportunities for citizen participation. This research is started from the identification of environmental conditions related to empowerment, as well as the dimensions carried out in tourism development. This study explores the community's involvement in developing tourism areas on Bangka Island, which creates empowerment opportunities for a more independent society. According to Setiani and Sugiyanto (2020) empowerment is related to efforts to involve and utilize the potential of a community in regional development, through planning and implementation. Interestingly, tourism development is still at the inception stage in this Island due to the low contribution to the Gross Domestic Product (GDP) sector and regional income sector despite various government efforts. Several new areas are managed and developed to ensure proper planning and empowerment. Although Bangka is widely known as an island with promising tourism potential, the impact of the booming Laskar Pelangi on Belitung Island (Ibrahim et al., 2019) has helped popularize both Islands, which are located in one province with similar characteristics. This study provides adequate analysis on strategies utilized by the empowerment sector in the development of ecotourism areas on Bangka Island. Several preliminary studies carried out on tourism development on Bangka Island, only focused on the development strategy, potential, and existing conditions of tourism (Hartoko et al., 2021; Megawandi, 2020; Purnaweni et al., 2019; Ariefianda et al., 2019; Futaesaku, 2019). Furthermore, these studies are not in accordance with the level of community empowerment, and this is the novelty position of this research.

\section{ECOTOURISM 'STARTUP' ON MINING ISLAND}

Bangka Island has the largest tin reserves in Southeast Asia. This area has been mined for over 400 years, starting from the Dutch colonial period to the current regime. It tends to industrial needs globally and plays a central role in various manufacturing activities. As a non-renewable commodity, tin is competed periodically. However, even in the transition of power, both in the pre-independence and modern history of Indonesia, the governance and distribution of tin has always been problematic. In the modern history, tin plays an important role as the mainstay commodity that supports people and a regional autonomy history. Furthermore its decentralization to regions, the management authority is still a trade-off. Recently, the central government withdrew the authority in issuing permits through Law Number 4 of 2020 concerning Minerals and Coal.

Apparently, the impact caused by mining is yet to be resolved. Therefore, this community is trying to escape from the shadow of tin dependence by trying to develop the tourism sector. Tin mining has been going on in Bangka Island since 1998, from the New Order under Suharto to the Reform Order under the regime of regional autonomy and democracy expansion.

Long before the accessibility of tin mining, the people in this area depended on the marine and plantation sectors. However, when access was granted along with the division of authority between the central and local governments, individuals and groups turned massively to the tin mining sector, both legally and illegally. Previously, people were only spectators in the tin exploitation process because the central government-controlled it entirely through state and private companies.

The open tin mining era is the result of a political concession between the local and the central government. Through the division of authority, locals are given a larger portion to regulate themselves, with the opportunity to form a more autonomous government through the formation of provinces. The Bangka Belitung Islands then became a separate province from South Sumatra and at the same time marked the acquisition of two regional autonomy privileges, with access to manage tin freely. However, the process of job shifting, as well as the regional autonomy formation, had a major impact on the local political system and resources. This transition was followed by changes in various things, including social relations in work, price fluctuations, economic activity, and environmental impacts due to massive tin mining (Nurtjahya et al, 2017; Ibrahim et al., 2018b; Ibrahim et al., 2019c). The environmental hazards awareness is associated with shared anxiety and has met with quite massive opposition in the construction process due to the massive dependence of people on tin. Local governments are trying to determine new economic alternatives by developing the tourism sector. It is wide open because the regional pattern provides the opportunity to develop the area to be like Bali, Lombok, or Hawaii in the United States with their beautiful beaches, coastal nature, and archipelago. The local government has programmatically attempted to encourage the development of the tourism sector, although it is still dealing with the environmental impacts. It is important to visualize their seriousness in preparing the tourism sector in the middle of tin mining's strong grip. The development of ecotourism has the potential to support conservation and save the environment in many ways (Hadmoko et al., 2021).

By analyzing the Regional Development Plans for these islands it was discovered that the local governments consisting of the provincial, district, and city governments, rely on tourism. The study carried out by Ibrahim et al., (2019) reported that local leaders have included tourism in various campaign agendas (Imelda, 2020). However, technically it has not been maximally worked on in planning documents that are integrated with other sectors. Therefore, with the existence of special offices for tourism, it is clear that tourism development efforts are a priority sector of the government.

According to Sulista et al (2019) and Ibrahim et al (2018c), tourism development in this area is running warmly along with tin mining which is currently experiencing a shift from the awareness aspect of long term environmental damage. Although the contribution to the economy society still needs to work hard. Data from the Bangka Belitung Central Statistics Agency (2020) showed a good development with several records, including the growth of star and non-star hotels and the number of visits. The following data shows some indicators of the tourism development sector. 
Table 1 shows that the number of facilities is relatively limited with an average stay and low occupancy rate. It also indicates that tourism development tends to increase rapidly on Belitung Island (Harefa, 2020), with limitation on Bangka Island. Belitung has only 2 regencies with 66 non-star hotels out of 142, while Bangka Island has 5 regencies with 30 out of 55 star-hotels available. This shows that there is a disparity in development between the islands and the province area. According to Megawandi's records (2020) tourism sector contributed $4.06 \%$ to Bangka Belitung's GRDP in 2017. Therefore, the provinces of both Islands are still trying to maximize tourism.

Table 1. Tourism facilities in the Bangka Belitung Islands Province

\begin{tabular}{|l|c|}
\multicolumn{1}{|c|}{ Indicator } & Total \\
\hline Number of Star hotels & 55 \\
\hline Number of Non-star Hotels & 142 \\
\hline Average stay of foreign guests & 3.03 \\
\hline Average stay of domestic guests & 1.62 \\
\hline Star hotel occupancy rate & 21.59 \\
\hline Non-star hotel occupancy rate & 13.47 \\
\hline
\end{tabular}

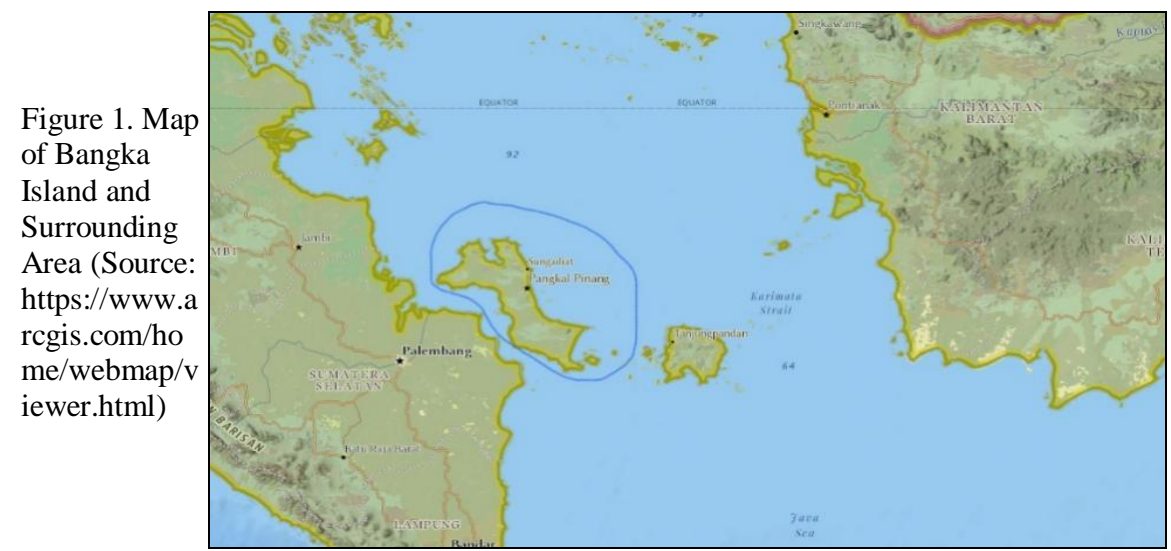

\section{COMMUNITY EMPOWERMENT IN ECOTOURISM DEVELOPMENT}

The development of an area is intended to provide benefits to residents' and promote the community. In this context, it is important to determine how development encourages people to become empowered. Zimmerman (2000) stated that empowerment analysis is based on the process (empowering) and achievement (empowerment). It focuses on analyzing access to resources, the openness of government structures, and sensitivity to differences at the community level. Meanwhile, in terms of achievements, it is important to focus on the analysis of institutional coalitions, plural leadership, and citizen participation skills. Perkins (1995) stated that at the community level, the empowerment process includes collective action to gain access to government and other resources. Therefore, wider connections are an important issue in empowerment, which is in accordance with the research carried out by Lord and Hutchison (1993). According to them, empowerment requires practical, moral support, and mentoring support, which are associated with direct involvement, motivational support, and mentoring process, respectively. It is important to note that empowerment is a process (Lord and Hutchison, 1993; Mernin, 2017; Aghazamani and Hunt, 2017; Cavalieri and Almeida, 2018). Zimmerman (1995) stated that empowerment is an effort to give people the opportunity to control their destinies or influence decisions that affect their fate. Efforts to gain control, access to resources, and a critical attitude towards understanding the social context are important empowerment principles. Therefore, empowerment means (1) involving community members in the development process, (2) designing environmental identity, (3) partnership or cooperation, and (4) opportunities. According to Wilcox (1994) the stages of empowerment to achieve goals are initiation, preparation, participation, and continuity.

However, Weidenstedt (2016) reported that empowerment is not only a gap between the rich and the poor, the powerful and the non-powerful, or the underprivileged and the extravagant rather it is a broader construction of interests. This does not always mean an invitation for those that are not privileged, rather a meaning towards bigger changes. According to Zimmerman (2000), an empowered community consists of well-connected organizations. This also means that there is equal access to resources and opportunities for engagement. Empowerment at the community level becomes the focus during changes in the socio-political structure. This means that social change occurs when there is an effort to encourage economic orientation from mining to ecotourism on Bangka Island. Joo et al. (2019) stated that empowerment in tourism development need to move from individual to community. Furthermore, a good knowledge of tourism is needed to promote better empowerment efforts. Khalid et al. (2019) also stated that good empowerment in the world of tourism ensures its sustainability. This means, the better the empowerment the more successful the future of tourism in this area.

\section{STUDY METHOD}

This is a quantitative research with data obtained by proposing 15 questions. The location chosen was the natural tourism area on Bangka Island with a total of 13 points scattered in the Regency of Bangka, Central Bangka, South Bangka, West Bangka, and Pangkal Pinang City. Heads of the 5 closest households were selected from the right to the left sides of each area. The sample consists of 260 people spread across 14 tourist area locations. The respondents were asked 4 to determine their involvement in planning and implementing regional development, as well as their commitment to engagement.

\section{RESULT AND DISCUSSIONS}

\section{Ecotourism on Bangka Island}

Bangka is a tin island that has been mined by various authorities for hundreds of years, starting from the Sultanate of Palembang, Netherlands, England, Japan, and the Indonesian government. Every year, hundreds of tourists frequently visit this Island due to the numerous attractive areas. Unfortunately, this Island is currently experiencing lots of environmental damage due to tin mining (Firdaus and Endah, 2015; Hengky, 2017; Ibrahim et al., 2019; Pratama, 2019). Bangka Island is also synonymous with beautiful coastlines, which is similar to Belitung Island and synonymous with Laskar Pelangi. Located in the southern region of Sumatra, this Island is home to 4 regencies and a city. The Island is part of the Bangka 
Belitung Archipelago Province, formed in 2000. This area is also known as home to popular Yusril Ihza Mahendra, Ahok, and Andrea Hirata as national leaders from Bangka Belitung and a place of ethnic harmony for the Malays, Chinese, and many other ethnicities. The tourism areas on Bangka Island are generally based on nature by relying on relatively new and simple management. Generally, it is based on coastal areas, with some of its regencies/cities popular as new tourist destinations. Interestingly, residents' tourism management in this area is generally initiated with the majority supported by the local government in terms of providing basic facilities and infrastructure. The private sector manages some areas, however, the areas that are the object of this study are easily accessible to the public and relatively represent favorite coastal areas in each region. In this section, provides a general description of the tourist area being researched as a locus of study.

Matras Beach is one of the coastal areas in the Bangka Regency supervised by the local government and managed by local residents. It is a fine sandy area with strong waves, which residents favor because it has a sloping stretch of beach, a large parking area, and is relatively close to the city center. Another is Takari Beach, which is a coastal area conserved by a foundation. The landslide at the top of this beach along the coast is planted with neat and lined pine trees, thereby creating an unusual sight. A visit to this beach costs no money because it is managed by local residents. Its slope and wide stretch of sand make Takari Beach a favorite place for families to spend time. Unlike Takari, there are fees attached to the Temberan Beach, located in the Air Anyir Village area, Bangka Regency, despite the fact that it is managed by residents. The voluntary admission fee collected at the location close to the eastern causeway, and the newness of this area, have made Temberan Beach attractive to the community. In this regency, Tikus Emas Beach is also an interesting area of study because it has adequate facilities. Apart from its soft sandy nature, other facilities include diving, large parking lots, and manicured trees.

This study analyzes two coastal and non-coastal areas in Central Bangka Regency. The first is Tapak Antu Beach, located in Batu Belubang, and one of the new tourism areas generally under supervision by the local government, with local residents' daily involvement. Tapak Antu Beach is known for its historical rocky areas with large footprints, which raises residents' curiosity. There are also mangroves around this beach with the addition of a small pier which adds to the attraction of tourists. The second is Kebang Kemilau Beach, an interesting area located on the edge of the main road and included in Arung Dalam Village's administrative area. This Beach is easy to reach, visited by tourists, and managed by both local government and residents are involved, as cleaners and sellers of food and drinks. The third is the Mangrove area in West Kurau, developed by one of the local residents and grouped into a community. This area comprises river cruising tourism, which attracts tourists, thereby transforming into a bustling and popular place on Bangka Island. Meanwhile, Central and South Bangka's border area comprises a famous lake known in recent years for its blue water, named the Kaolin Lake. This is an ex-tin mining area forming a former puddle and known as Kolong by local residents. In South Bangka Regency, 2 tourist objects are being studied, namely Batu Belimbing and Tanjung Kerasak Beach. Batu Belimbing is a unique area with large stones resembling star fruit above other rocks, which attracts yearly tourist visits. Furthermore, this area consists of various facilities built by the local government, and residents are involved in several roles, including parking attendants, salespeople, and tour guides. Meanwhile, Tanjung Kerasak Beach, located in the Toboali Sub-District, was initially popular to easily witness a solar eclipse. Furthermore, this area is famous for its beautiful beaches with clusters of rocks.

This research analyzed 2 tourists objects in West Bangka Regency, namely Batu Rakit and Tanjung Kalian Beach. Batu Rakit is a beach built with government facilities to prevent silting and abrasion of the coastal area. The government built water flow regulating facilities around residential areas to attract tourists because it connects the coastal area with residents' housing. This area acts as a relaxation region for families and young people. Meanwhile, Tanjung Kalian is a beach located on the port edge of the large vessel berth. This beach has a lighthouse from the Netherlands with an attractive coastal area due to its coastline and a bustling view of the leaning vessels. In Pangkal Pinang, Pasir Padi Beach is the most attractive area for visitors and approximately $5 \mathrm{KM}$ from the city center. Apart from having adequate facilities, this beach has a long line with sloping shapes, and local residents are involved in the managerial process.

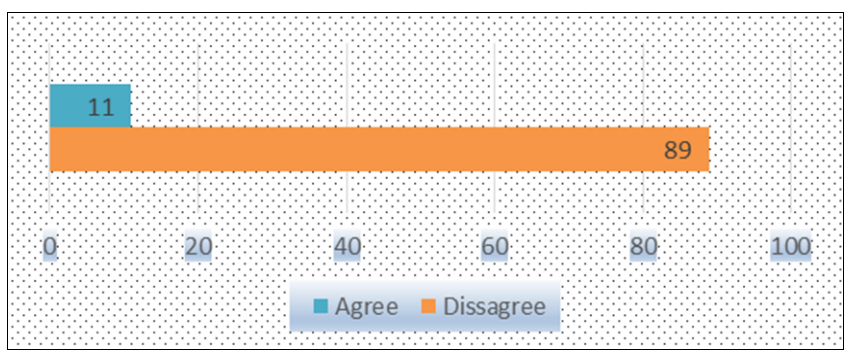

Figure 2. The involvement from start

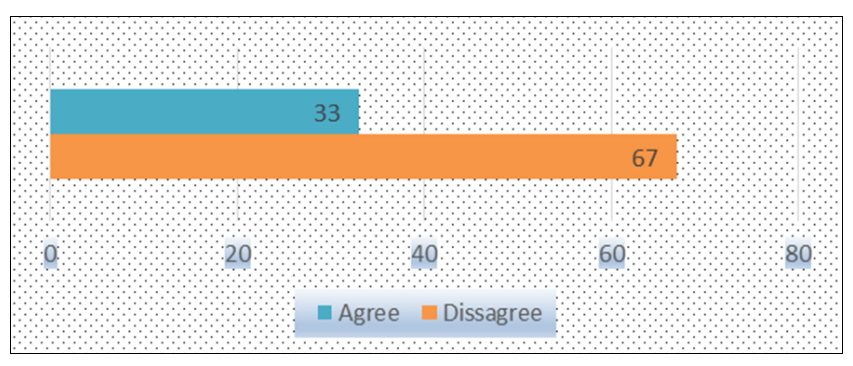

Figure 3. Community involvement from start

\section{Weak involvement in the initial planning}

According to studies, it is important to empower residents around tourist destination areas to boost local economies. Giriwati et al. (2019) stated that the community involvement scheme has at least three stages, namely planning, implementation, and profit-sharing. In developing tourism areas, it is important to determine the resident involvement according to the government or tourism area managers' initial plans. The graph above shows that $11 \%$ of respondents stated that they were involved instead of the remaining $89 \%$. It is also important to ask the involvements of many residents in the initial planning process. The following figure presents the respondents 'answers regarding their involvements. The graph above shows that approximately $33 \%$ of respondents stated that there were many residents involved from the start, as opposed to 67 $\%$. This means that most respondents stated that not many residents were involved in the area process. Another important 
question asked by the authors is regarding the government's initial plans to provide or manage the local people from the area development plan. The following are the respondents' answers: Based on the graph above, only $26 \%$ of the respondents agreed that the government had described the benefits from developing tourist destinations in their area, while $74 \%$ disagreed.

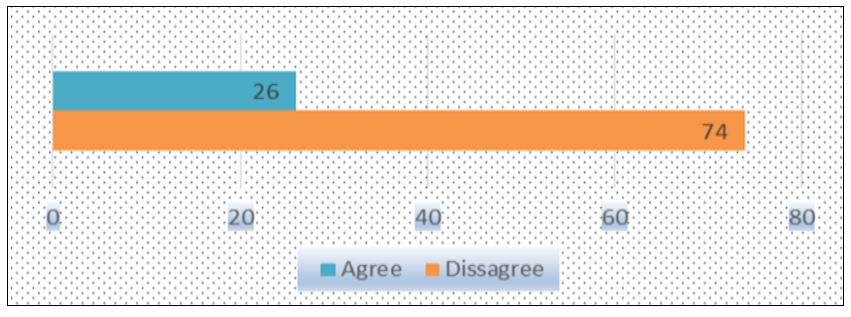

Figure 4. Benefits overview from start

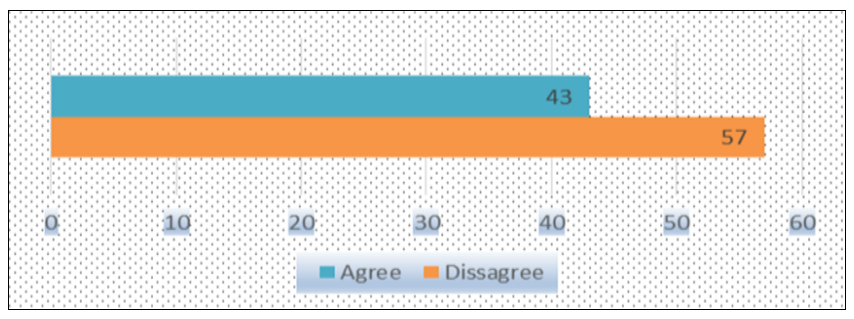

Figure 5. Opportunity to get involved

\section{Low involvement}

Local residents need to be involved in the tourism development process. Therefore, the authors asked the respondents whether the same opportunity is given to all residents or only to certain groups. The following table shows the respondents' answers: A total of $57 \%$ stated that not all residents have the same opportunity to be involved in the area's management and development. The authors also asked for their full-time involvement in the development of the area, which was opposed by $89 \%$ of the respondents. This means that their dependence on the management of these tourism areas is still very limited. Meanwhile, only $11 \%$ of respondents stated that they were involved full-time. This is in line with the question of whether residents get the same opportunity to be involved or not. The majority stated that not all residents had the same opportunity to be involved. Meanwhile, this study needs to determine the government or managers' ability to provide education to local residents on tourism and hospitality management. This is because many tourism areas do not pay attention to aspects of good governance, while at the same time, not all residents understand how to be part of the process in developing a tourist-friendly environment. The following are respondents' answers: The graph above shows that approximately $80 \%$ of respondents stated the unavailability of education on tourism and hospitality management. This means that residents do not fully understand what they need to carry out and the process needed. Furthermore, the authors asked the respondents if the tourism development process empowered them. The graph shows that approximately $68 \%$ of respondents stated that they had not been empowered by the government or the tourism area manager, as opposed to the remaining $32 \%$. The empowerment process is considered inadequate assuming the flow of respondents' answers is limited. This means that people do not feel that they are significantly involved, from planning to management, as well as in getting the benefits.

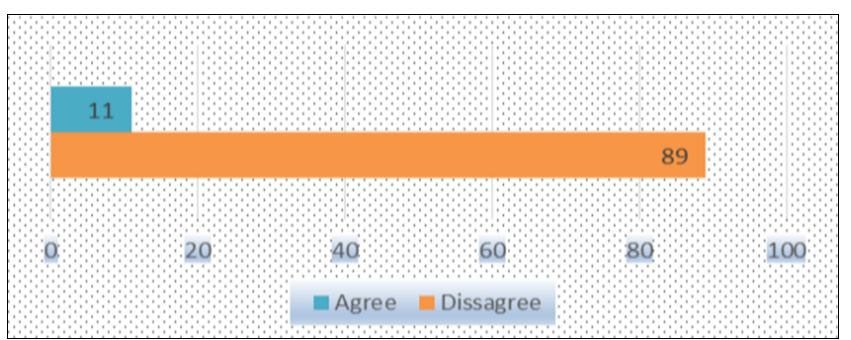

Figure 6. Full time involvement

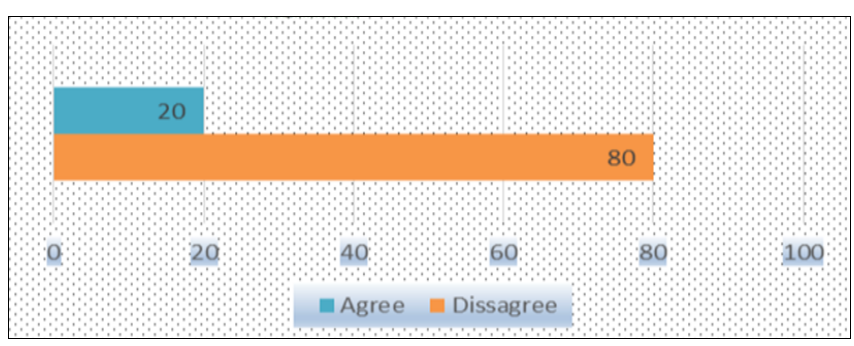

Figure 7. Education about governance

\section{Area development impact anomaly}

Development of tourism areas and the terminology of empowerment mean enabling the surrounding communities to gain economic benefits. Therefore, the local residents were asked their opinion regarding the economic impact of these tourism areas. The following are the answers from the respondents: Approximately $57 \%$ stated that they did not get economic benefits instead of the remaining $43 \%$. This means that the majority did not receive economic benefits from the development of the area. Furthermore, the authors asked the respondents for other benefits associated with their answers, as shown in the following graph. The graph above shows that approximately $71 \%$ of the respondents stated that there were other benefits asides from the economic advantages, as opposed to the remaining $29 \%$. Furthermore, the respondents were asked to determine the impact of tourism development on residential areas. The graph shows that $77 \%$ of respondents agreed that there was a broad impact on the areas, while the remaining $23 \%$ disagreed. The question regarding the possibility of the area having a promising future due to tourism development showed that only $40 \%$ were optimistic, while the remaining $60 \%$ were pessimistic. This means that for most respondents, the area's development is not very promising for the future. Therefore, this graph is basically related to the people's optimism towards the development of the area. Meanwhile, social changes due to a conflict are often encountered at the beginning of the tourism area development process due to the suitability of tourism conditions with the resident's culture. Therefore, the respondents were asked whether the development of the tourism area was in accordance with the resident's culture. Interestingly, $82 \%$ stated no problem, while the remaining $18 \%$ reported unsuitability between the developing conditions and residents' culture. Therefore, to explore the above questions, this study specifically asks for the bad impacts caused by the development of these tourism areas. The following provides answers to the questions. The graph above shows that $88 \%$ of the respondents stated that there were no bad impacts caused by the development of tourism areas instead of the remaining $12 \%$. 


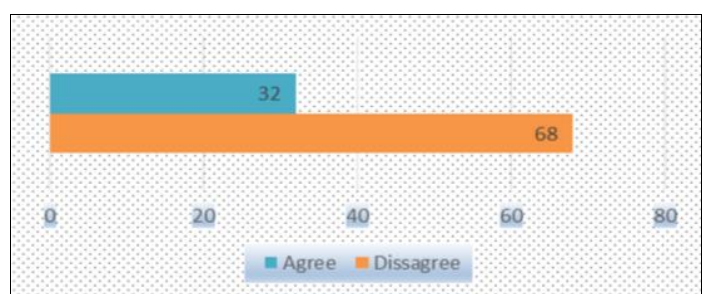

Figure 8. Feeling empowered

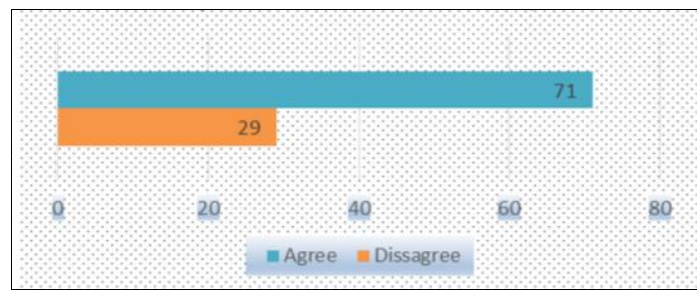

Figure 10. Benefits outside the economy

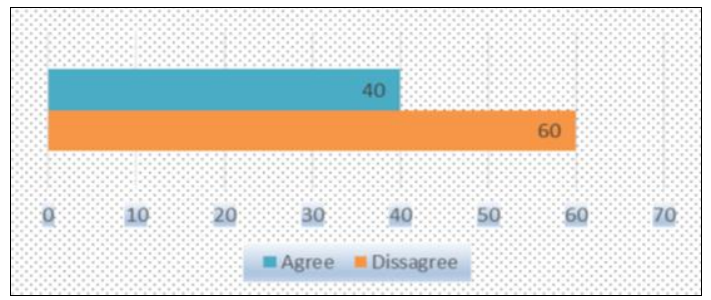

Figure 12. Promising the future

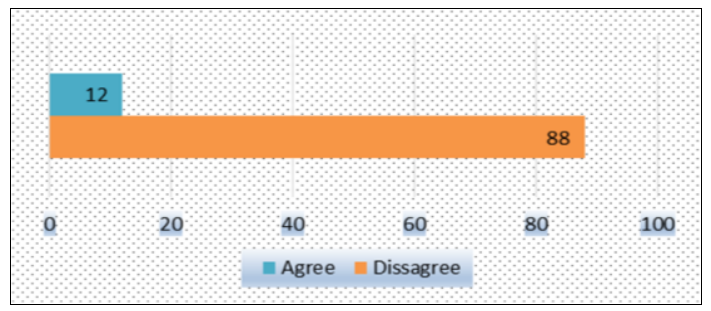

Figure 14. Bad impact on the region

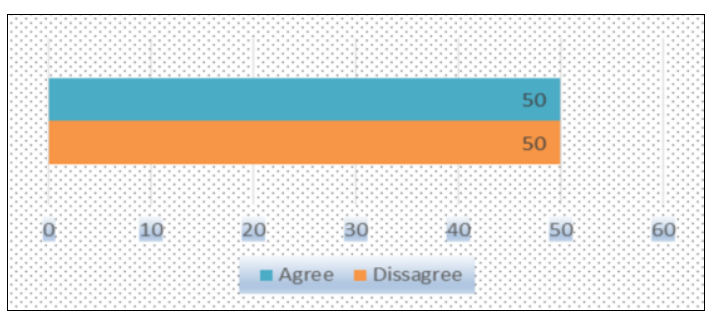

Figure 16. Commitment to involve

\section{High commitment to involvement}

The commitment involved in the development area is shown in the following graph: The study shows that $99 \%$ of respondents supported the development of tourism areas around them, while the remaining $1 \%$ objected.

The respondents' commitments were determined using the following answers. Commitment to support does not necessarily mean getting involved, rather it is associated with the respondents' answers, which are divided into two. Approximately 50 $\%$ stated their ability to continue, while the remaining $50 \%$ opposed being involved.

\section{Pseudo empowerment}

According to Zimmerman (1995) adequate attention need to be paid to several factors, including the basic involvement and opportunity for equal engagement opportunities. In this study, the level of empowerment is observed in some fundamental factors. The first is associated with the strategy utilized by a community in the planning process, followed by the second, which is the extent to which the empowerment process enables the community to be more empowered, especially on an economic basis. The third is the strengthening aspects of locality and developing cultural values of the surrounding community, while the fourth is the commitment of residents involved due to individual interests.

The simplified result is shown in the following table: The data above shows some interesting things, the first is related to the planning process. Participatory planning should involve the community early in a variety of forms. Communicating effectively to promote community participation is a simple thing that should be carried out by governments or managers. 
Indika and Vonika (2016); Wahyuni (2018); Putri et al., (2020) stated that planning involves local communities from the start, with the benefits extending to touch economic and social levels, therefore local communities cannot be neglected in tourism development (Ludic and Yekela, 2020; Naja et al., 2021). Residents surrounding this area generally stated that they were less involved in the planning process for developing tourist destinations. Furthermore, local residents did not feel that they had the same opportunity to be involved, while others thought that the government or management did not provide an overview of the potential benefits obtained when residents were involved as shown in Table 2 with negative tendency for all indicators. This means that residents generally felt that they had not been involved from the start.

The results of qualitative interviews with local residents show that the empowerment only focuses on local institutions such as youth organizations and village government officials. This shows that planning is still organization-based despite the community involvement carried out through institutional groups in the associated region. Due to the fact that planning involving local residents has not been maximized, it is not surprising that this study also finds other interesting things, namely the less optimal involvement of local residents. Khalid et al., (2019) stated that empowerment is more synonymous with collective action and not individual. Secondly, the residents stated that only a small proportion is fully involved in the development process. Those involved are generally village government officials or certain people. Residents also stated that they were not given enough education and felt less empowered in the end. The study carried out by Eraku et al. (2021) showed the maximum local community involvement with many benefits such as economic (Sumarmi, 2020; Utomo et al., 2020; Waridin and Astawa, 2021) and local wisdom utilization (Marlina et al., 2020; Kodir et al., 2020). Akbar et al. (2021) conducted a research on the importance of the government's role in bridging community participation in tourism development.

Thirdly although the local residents do not feel the economic impact, other resources need to be obtained. This means that community support for the development of this area is not only due to an impetus for economic benefits (Nordin et al., 2014) rather it is associated with changes and broad impacts imagined to change their area. Table 2 showed the negative tendency for economic benefits indicators and prospects, with positive results for non-economic benefits, significant impacts, cultural suitability, and bad impacts on the surrounding environment. The interview shows that the aspect of pride is more dominant as another perceived benefit. Their area becomes crowded, and the construction of facilities also provides other benefits.

This is in line with the research carried out by Mensah (2017), which stated that even though community empowerment is less optimal, the development of tourism area makes the region well known to many people. The residents agreed that there was no bad impact from the development of this area. This means that there is support for the development of tourism areas, not only for economic benefits. The data above shows that although the development of tourism area is not very promising for the future, residents feel it is still in accordance with the local culture. Fourthly, this study also found that almost all respondents expressed their support for the development of their tourism areas as showed by Table 2. However, the need to be directly or indirectly involved yields a balanced answer. This shows that the community agrees to the development, however, their respective involvement does not matter. The authors stated that although tourism is insignificant for economic gain, real support is provided. Therefore, although planning was not carried out in a participatory manner based on the data, support was still provided. This means that the development of the area is projected to positively impact the surrounding residents' areas and automatically give promises for wider development. This is known as pseudo empowerment, which does not only focus on the process of building economic capacity, rather it also provides other values capable of boosting the image of the region.

According to Scheyvens (1999), this condition is artificial because community empowerment has at least 4 frameworks, namely economic, psychological, social, and political. Meanwhile, Putri et al. (2020) stated that the government needs to focus on hard and soft skills. Pseudo empowerment does not focus on empowerment content, rather on pride for area development, projected to provide great benefits for tourist destination areas. According to Zimmerman (2000), it is difficult to achieve the level of empowerment in this case due to inability to carry out the empowerment process optimally. Although this study found that people in tourist sites do not always associate aspects of empowerment with economic benefits, they have not felt a significant impact beyond the popularity pride in the area. Therefore, the government and stakeholders need to review their perspective on the empowerment process. This is in order to avoid the process of obtaining a half-hearted transformation to the tourism sector (Ibrahim et al., 2020) and the artificial empowerment process. Furthermore, enabling the community to be independent and empowered is a fundamental need that needs to be evaluated to achieve economic, social, and cultural aspects and encourage wider benefits from empowerment. Joo et al. (2019) stated that good empowerment move from individual to community level, thereby promoting peoples' ability to understand the nature of tourism development. Furthermore, Khalid et al. (2019) stated that the sustainability of tourism in this area is also not promising, therefore, more studies need to be conducted.

\section{CONCLUSION}

The development of tourism areas, especially those based on nature as an object, need to be able to involve local residents for wider benefits. Therefore, community empowerment plays an essential role in utilizing local wisdom as an inseparable part of this development and providing benefits felt directly by residents around tourism areas. Generally, ecotourism areas on Bangka Island have recently developed widely in line with the increasing interest in environmentbased tourism. Therefore, community involvement needs to be the basic spirit of this development because it starts with integrated naturalization with residents around tourism areas. This study reveals that community involvement is generally limited to the initiating, developing, and operating processes, which are open to the public. In general, community involvement is elitist and tends to focus on the involvement of existing local institutions hence there seems to be elitism in the empowerment process. Furthermore, although local residents' involvement is relatively limited, they actually still support and hope that the tourism areas in their region continue to develop. Economically, the benefits felt by local residents are considered low, and the majority are not sure of their future involvement. However, this study reveals strong support from residents and the perception that tourism areas' development does not adversely affect their area. There is a sense of pride outside of economic affairs which is the basis for the benefits expected from the development of an ecotourism area. 
Therefore, the authors stated that empowerment is pseudo and limited, although it gets support because of noneconomic benefits. Meanwhile, a comprehensive dimension of empowerment needs to include the benefits of physical development, economic advantages, and other empowerment, which enable the community to get broad benefits for the development of an area. This study focuses on the empowerment aspect in the ecotourism development on Bangka Island based on the views of residents around the area. Further study capable of examining the views of managers and elements of policymakers in the regions need to be conducted. In addition, statistical measurements on the impact of ecotourism development on local economic development, such as home industries, and the economy of residents that depend on its management, such as housewives and those with disabilities need to be further studied.

\section{Acknowledgments}

The authors are grateful to the Deputy for Strengthening Research and Development, Ministry of Research and Technology/National Innovation Agency, for funding the publication of this research through the Basic Research Grant scheme 2019-2021 with Decree Number 7/E/PT/2019 and contract number 185.A/UN.50.3.1/PP/2019.

\section{REFERENCES}

Akbar, I., Myrzaliyeva Z.K., Tazhekova A.Z., Saulembayev, A.T., \& Kenzhebay R.N. (2021). Evaluation of Community-Based Ecotourism Development Status in the Aksu-Jabagly Nature Reserve, Kazakhtan. GeoJournal of Tourism and Geosites, 35(2), 381389. https://doi.org/10.30892/gtg.35216-662

Aghazamani, Y., \& Hunt, C.A. (2017). Empowerment in Tourism: A review of peer-reviewed literature. Tourism Review International, 21(4), 333-346. https://doi.org/10.3727/154427217X15094520591321

Ariefianda, R., Hidayat, J.W., \& Maryono, E. (2019). Assessment of Tourism Suitability in Natural Tourism Object of Lengkuas Island, Sijuk District, Belitung Regency, Bangka Belitung Province. E3S Web Conference, 125(01011), 1-5. https://doi.org/10.1051/e3sconf/201912501011

Bidayani, E., \& Kuniawan (2020). Conflict Resolution in Coastal Resources Utilization among Fishermen and Unconventional Tin Miners. Society, 8(1), 13-22. https://doi.org/10.33019/society.v8i1.139

Butar-Butar, R. R., Soemarno. (2012). Community Empowerment Effort in Sustanaible Ecotourism Management in North Sulawesi. Indonesia, $J-P A L, 3(1), 1-7$. https://jpal.ub.ac.id/index.php/jpal/article/view/120

Cavalieri, I., Almeida, H. (2018). Power, Empowerment and Social Participation-the Building of a Conceptual Model. European Journal of Social Sciences Education and Research, 12(1), 189-199. https://doi.org/10.26417/ejser.v12i1.p189-199

Eraku, S.S., Permana, A.P., Rijal, A.S., Baruadi, M.K., Hendra, \& Baruadi, M.N. (2021). Analysis of Ecotourism Potential of Botutonuo Beach in Bone Bolango Regency, Indonesia. GeoJournal of Tourism and Geosites, 36(2l), 624-629. https://doi.org/10.30892/gtg.362spl09-691

Futaesaku, K. (2019). Reconstruction and Transformation of Regional Culture through Tourism: The Case of Bangka Belitung Province. Advances in Social Science, Education and Humanities Research, 367, 30-55. https://doi.org/10.2991/icdesa-19.2019.11

Giriwati, N.S.U., Hawa, L.C., Pamungkas, S.T., Iyati, W., \& Hidayat, A.R.T. (2019). Local Community Participation in Ecotouri sm Development: The Case of Sumberwangi Hamlet Destination, East Java, Indonesia. PEOPLE: International Journal of Social Sciences, 5(1), 81-98. https://dx.doi.org/10.20319/pijss.2019.51.8198

Firdaus, N., \& Endah, N.H. (2015). Accelerating the Development of Bangka Island through Sustainable Tourism by Strengthening the Roles of Multi-stakeholders. International Journal of Administrative Science \& Organization, 22(3), 169-179. http://journal.ui.ac.id/index.php/jbb/article/view/6611/3739

Harefa, M. (2020). Impact of Tourism Sector on Regional Income in Belitung Regency. Jurnal Ekonomi \& Kebijakan Publik, 11(1), 6577. https://doi.org/10.22212/jekp.v11i1.1487

Hadmoko, D.S., Marfai, M.A., Malawani, M.N., Mutaqin, B.W., Risanti, A.A., \& Permatasari, A.Z. (2021). Coastal Geomorphosites Assesment for Ecotourism Development in East Lombok, Indonesia. GeoJournal of Tourism and Geosites, 36(21), 589-596. https://doi.org/10.30892/gtg.362spl05-687

Hartoko, A., Atmaja, E.J., Firmansyah, \& Basuki, G. (2021). New concept of coastal geopark ecotourism based on integrated coastal resources clusters in Bangka Belitung (Banca-Biliton) Islands, Indonesia. Journal of Coastal Zone Management, 24(4). https://www.longdom.org/abstract/new-concept-of-coastal-geopark-ecotourism-based-on-integrated-coastal-resources-clusters-in-bangkabelitung-bancabiliton-79455.html

Hengky (2017). Beholding Taniung Pesona Coastal-ecotourism in Bangka Islands, Indonesia. Business and Economic Research, 7(2), 2017, 102-117. https://doi.org/10.5296/ber.v7i2.11552

Ibrahim, Haryadi, D., \& Wahyudin, N. (2018a). Already Dependent: A Depencency Analysis of market activity on tin mining in Bangka Belitung. E3S Web of Conference, (91) 03004, 1-6. https://doi.org/10.1051/e3sconf/20199103004

Ibrahim, I., Haryadi, D, \& Wahyudin, N. (2018b). Knowledge of the context, behavior, and expectations of miners in relation to the tin mining policies and practices in Bangka Belitung. Masyarakat, Kebudayaan, dan Politik, 3(4), 358-367. http://dx.doi.org/ 10.20473/mkp.V31I42018.358-367

Ibrahim, Haryadi, D., \& Wahyudin, N. (2018c). The Social Dilemma of Tin Mining Non-Miners People: A Comparative Study between Bangka and Belitung People's Perception. E3S Web of Conference, 73(02014), 1-6. https://doi.org/10.1051/e3sconf/20187302014

Ibrahim, I., Haryadi, D., \& Wahyudin, N. (2019). Between Fishing, Mining, and Suction Vessel: The Compromise of Teluk Limau People, West Bangka, On Tin Mining Aggression. PEOPLE: International Journal of Social Sciences, 5(1), 178 - 185. https://dx. doi.org/10.20319/pijss.2019.51.178185

Ibrahim, I., Zukhri, N., \& Rendy, R. (2019a). Between Tourism and Ecology: Review of Political Policy Commitments on Ecotourism Development in Bangka Belitung. E3S Web of Conferences, 118(04008), 1-4. https://doi.org/10.1051/e3sconf/201911804008

Ibrahim, I., Zukhri, N., \& Rendy, R (2019b). Between Natural Tourism, the Booming of Laskar Pelangi Film, and the Image of Environmental Damage: Measuring the Perception of Regional Tourist on Bangka Belitung Tourism. Journal of Physics: Conference Series, 1351(012107), 1-9. https://doi.org/10.1088/1742-6596/1351/1/012107

Ibrahim, I., Zukhri, N., \& Rendy, R. (2020). From Economics to Political Economy: Half-hearted Transformation of the Ecotourism Sector in Bangka Belitung. Jurnal Wacana Politik, 5(2), 174-184. https://jurnal.unpad.ac.id/wacanapolitik/article/view/30631/pdf

Indika, D.R., \& Vonika, N. (2016). Rural Tourism Development Using Ecotourism as a Model of Community Empowerment in Cireundeu Indigenous Village, Cimahi, West Java, Indonesia. International Conference of Integrated Microfinance Management (IMM-16), Atlantis Press, 0148-0154. https://doi.org/110.2991/imm-16.2016.23

Joo, D., Woosnam, K.M., Strzelecka, M., \& Boley, B.B. (2019). Knowledge, empowerment, and action: testing the empowerment theory in a tourism context. Jurnal of Sustanaible Tourism, 28(1), 69-85. https://doi.org/10.1080/09669582.2019.1675673

Khalid, S., Ahmad, M.S., Ramayah, T., Hwang, J., \& Kim, J. (2019). Community Empowerment and Sustainable Tourism Development: The Mediating Role of Community Support for Tourism. Sustainability, 11(6248), 1-14. https://doi.org/10.3390/su11226248 
Kodir, A., Ahmad, R., \& Meiji, N.H.P. (2020). The Dynamics Access on Tourism Governance in Wakatobi National Park. GeoJournal of Tourism and Geosites, 32(4), 1376-1383. https://doi.org/10.30892/gtg.32427-583

Lord, L., \& Hutchison, P. (1993). The Process of Empowerment: Implications for Theory and Practice. Canadian Journal of Community Mental Health, 12:1, 5-22. https://www.johnlord.net/web_documents/process_of_empowerment.pdf

Ludic, K.G., \& Yekela, S. (2020). Resident's Perception of The Environmental Impact of Tourism: A Case Study of The Bawa Community in Butterworth, South Africa. GeoJuournal of Tourism and Geosites, Year XIII, 33(4), 1527-1531, https://doi.org/10.30892/gtg.334spl12-603

Mafruhah, I., Mulyani, N.S., Istiqomah, N., \& Ismoyowati, D. (2018). Development of ecotourism based on Community Empowerment (A Case Study of Kebumen Regency). Jurnal Ekonomi Pembangunan: Kajian Masalah Ekonomi dan Pembangunan, 19(2), $196-206$. https://doi.org/10.23917/jep.v19i2.6996

Marlina, Sumarmi, \& Astina, I.K. (2020). Sustanaible Marine Ecotoruism Management: A Case of Marine Resource Conservation Based on Local Wisdom of Bojo Mola Community in Wakatobi National Park. GeoJournal of Tourism and Geosites, 32(4), 1317-1323. https://doi.org/10.30892/gtg.32419-575

Megawandi, Y. (2020). Tourism Development in the Province of the Bangka Belitung Islands in a Whole of Government Approach. Jurnal Widyaiswara Indonesia, 1(2), 108-119. https://ejournal.iwi.or.id/ojs/index.php/iwi/article/view/27

Mensah, I. (2017). Benefit and Challenges of Community-Based Ecotourism in Park-Fringe Communities: The Case of Mesomagorof Kakum National Park, Ghana. Tourism Review International, 21(1), 81-98. https://doi.org/10.3727/154427217X14866652018947

Mernin, L. (2017). The Empowerment Model: Turning Barriers into Possibilities. Palaestra, 31(2), 19-26. https://js.sagamorepub.com/ palaestra/article/view/8429

Naja, D.A., Suprayogi, S., Marfai, M.A., \& Mardiatno, D. (2021). A Study on the Social Networks Analyses of Dive Centers and Sustanaible Tourism Development in Pemuteran Bali, Indonesia. GeoJournal of Tourism and Geosites, 36(21), 603-615. https://doi.org/10.30892/gtg.362spl07-689

Ngurah, I.D.G., \& Utama, M.S. (2018). The Role of Social Capital, Tourism Potential and Community Empowerment in CommunityBased Tourism Development in Tourism Strategic Areas More. E-Jurnal Ekonomi dan Bisnis Universitas Udayana, 7(6), 2018, 1647-1666. https://jitode.ub.ac.id/index.php/jitode/article/view/353

Nordin, O.A.S., Lonik, K.A.T., \& Jaafar, M. (2014). Empowering Local Communities through Tourism Entrepreneurship: The Case of Micro Tourism Entrepreneurs in Langkawi Island. SHS Web of Conferences, 12(01101), 1-9. https://doi.org/10.1051/shsconf/ 20141201101

Nugroho, I., Negara, P.N., \& Yuniar, H.R. (2018). The Planning and the Development of the Ecotourism and Tourism Village in Indonesia: A Policy Review. Journal of Socioeconomics and Development, 1(1), 43 - 51. https://doi.org/10.31328/jsed.v1i1.532

Nurtjahya, E., Franklin, J., \& Agustina, F. (2017). The Impact of tin mining In Bangka Belitung and its reclamation Studies. MATEC Web of Conference, 101(04010), 1-6, https://doi.org/10.1051/matecconf/201710104010

Perkins, D.D. (1995). Empowerment Theory, Research, and Application. American Journal of Community Psychology, 23(5), 569-579. https://link.springer.com/article/10.1007/BF02506982

Pratama, S. (2018). The Politial Economy Dimension towards Conflict of Mining Governance (Case Study: Bangka Belitung Governoor's Regulation about the Moratorium of PT Timah, Tbk Offshore Tin Mining 2016). Jurnal Wacana Politik, 3(1), 40-53. https://doi.org/10.24198/jwp.v3i1.16084

Purnaweni, H., Kismartini, Prabawani, B., \& Roziqin, A. (2019a). Politics and Business: The Policy on Tin Mining in Bangka. International Journal of Business and Economic Affairs, 4(3), 133-139. https://doi.org/10.24088/IJBEA-2019-43004

Purnaweni, H., Kismartini, Prabawani, B., \& Roziqin, A. (2019b). Bangka Belitung Islands: Great Potencies of Massive Environmental Impacts. E3S Web Conference, 125(09008), 1-5. https://doi.org/10.1051/e3sconf/201912509008

Putri, A.E., Khadijah, U.L.S., \& Novianti, N. (2020). Community Empowerment in the Depvelopment of Mangrove Tourism in Batu Karas of Pangandaran, West Java. GeoJournal of Tourism Geosite, 31(3), 972-978. http://gtg.webhost.uoradea.ro/PDF/GTG-3-2020/gtg.31306-529.pdf

Rosyida, I., Ullah, W., Helmi, A., \& Sasaoka, M. (2019). Adapting livelihoods to the impacts of tin mining in Indonesia: options and constraints. The Extractive Industries and Society, 6(4), 1302-1313. https://doi.org/10.1016/j.exis.2019.10.018

Scheyvens, R. (1999). Ecotourism and the Empowerment of Local Communities. Tourism Management, 20(2), $245-249$. https://doi.org/ 10.1016/S0261-5177(98)00069-7

Setiani, M., \& Sugiyanto, E. (2020). Community Empowerment in Supporting Tourism Village Development: Penusupan Village Study, Kebumen Regency, Central Java Province. Jurnal Sosial dan Humaniora, 5(9), 61-71. http://journal.unas.ac.id/populis/article/view/847/905

Sulista, S., Ibrahim, I., \& Pratama, S. (2019). Accomodation, Resistance, and Divided Community: Study of the Dynamics of Offshore Tin Mining Conflict between the Fishermen of the Coastal Area and Compaies in Bangka Island. PEOPLE: International Journal of Social Sciences, 5(3), 275-296. https://dx.doi.org/10.20319/pijss.2019.53.275296

Sulista, S. (2019). The Sustainability of Livelihoods of Villages around the Tin Mine in Bangka Islands. Jurnal Bina Praja, 11(1), 4352. https://doi.org/10.21787/jbp.11.2019.43-52

Sumarmi, Kurniawati, E., \& Aliman, M. (2020). Community Based Tourism (CBT) to Establish Blue Economy and Improve Public Welfare for Fishing Tourism Development in Klatak Beach, Tulungagung, Indonesia. GeoJournal of Tourism and Geosites, 31(3), 979-986. https://doi.org/10.30892/gtg.31307-530

Utomo, S.H., Wulandari, D., Narmaditya, B.S., Ishak, S., Prayitno, P.H., Sahid, S., \& Qodri, L.A. (2020). Rural-Based Tourism and Local Economy Development: Evidence from Indonesia. GeoJournal of Tourism and Geosites, 31(3), 1161-1165. https://doi.org/10.30892/gtg.31330-553

Wahyuni, D. (2018). Community Empowerment Strategy in the Development of Nglanggeran Tourism Village, Gunung Kidul Regency. Aspirasi: Jurnal Masalah-Masalah Sosial, 9 (1), 83-100. https://doi.org/10.46807/aspirasi.v9i1.994

Waridin, \& Astawa, I.P. (2021). Shifting of Land Use in Sustanaible Tourism: A Local Cultural Approach in Indonesia. GeoJournal of Tourism and Geosites, 35(2), 270-274. https://doi.org/10.30892/gtg.35201-647

Weidenstedt, L. (2016). Empowerment Gone Bad: Communicative Consequences of Power Transfers. Socius: Sociological Research for a Dynamic World, 2, 1-11, https://doi.org/10.1177/2378023116672869

Wilcox, D. (1994). Community participation and empowerment: putting theory into practice. Source: RRA Notes (1994), $21,78-82$. https://pubs.iied.org/sites/default/files/pdfs/migrate/G01549.pdf

Zimmerman, M.A. (2000). Empowerment Theory, Psychological, Organizational and Community Level of Analysis in Handbook of Community Psychology, Kluwer Academic/Plenum Publisher, New York. https://doi.org/10.1007/978-1-4615-4193-6_2

Zimmerman, M.A. (1995). Psychological Empowerment: Issues and Illustrations. American Journal of Community Psychology, 23(5), 581-599. https://doi.org/10.1007/BF02506983

*** BPS-Statistic of Kepulauan Bangka Belitung Province (2021). Bangka Belitung dalam Angka [Bangka Belitung Islands Province in Numbers]. https://babel.bps.go.id/publication/2021/02/26/0c50488f5da6ac10733d2095/provinsi-kepulauan-bangka-belitung-dalam-angka-2021.html

**** Imelda (2020). Babylon will prioritize the Tourism Sector, https://babelprov.go.id/content/tahun-2021-babel-akan-prioritaskan-sektor-pariwisata 